\title{
Extrinsic Factors Influencing Internal Auditors' Effectiveness in Jordanian Public Sector
}

\author{
Hamza Mohammad Alqudah ${ }^{1}$, Noor Afza Amran ${ }^{2} \&$ Haslinda Hassan ${ }^{2}$ \\ ${ }^{1}$ Tunku Puteri Intan Safinaz School of Accountancy (TISSA), University Utara Malaysia (UUM), Sintok, Kedah 06010, \\ Malaysia \\ ${ }^{2}$ Tunku Puteri Intan Safinaz School of Accountancy (TISSA), University Utara Malaysia (UUM), Sintok, Kedah 06010, \\ Malaysia \\ ${ }^{3}$ Tunku Puteri Intan Safinaz School of Accountancy (TISSA), University Utara Malaysia (UUM), Sintok, Kedah 06010, \\ Malaysia \\ Correspondence: Hamza Mohammad Alqudah, Tunku Puteri Intan Safinaz School of Accountancy (TISSA), University \\ Utara Malaysia (UUM), Sintok, Kedah 06010, Malaysia
}

Received: April 14, 2019 Accepted: May 13, 2019 Online Published: May 20, 2019

doi:10.5539/res.v11n2p67

URL: https://doi.org/10.5539/res.v11n2p67

\begin{abstract}
This study focuses on the extrinsic factors, namely, top management support, complexity, independence, and internal audit department's size that are out of internal auditors' control affecting their effectiveness in the Jordanian public sector. The current study also tries to improve understanding of the extrinsic factors affecting internal auditors' ability to achieve the assigned goals in order to highlight internal auditors' effectiveness. Resource-based and agency theories were used in developing the research model. Two sets of questionnaires were distributed among the financial managers and internal audit managers. The results reveal that top management support, independence, and the size of internal audit department play a significant and positive role on the effectiveness of internal auditors, whereas complexity of the task has been found to make a negative impact on the level of their performance. Given the significance of the public sector within the Jordanian economy, the findings are valuable for the internal audit function, regulators, and decision-makers in proposing new legislation and regulations of an internal audit function. Future studies may look into other factors that may restrict internal audit performance, such as organizational culture and pay satisfaction.
\end{abstract}

Keywords: internal audit, public sector, extrinsic factors, effectiveness, task complexity

\section{Introduction}

Recently, the Internal Audit function (IAF) has been modified to add value and enhance the organization's actions through affording a broad range of services. The IAF services have included assurance and operational audits, as well as consulting administration on a diversity of issues (Gramling, Maletta, Schneider, \& Church, 2004). Meanwhile, "the IAF in the government environment has been expanded considerably, in a bid to meet the demands to raise transparency, integrity and improvement level of government service delivery" (Alzeban, 2010, p. 16). The nature of IAF included compliance work, control assurance, and risk assessment (Gramling et al., 2004). Hence, IAF has played significant roles in corporate governance in many institutions since the early 1940s, and these roles have been developed over time (Moeller, 2004). They have been extended to encompass a consulting role, risk management, control assurance, and compliance work (Mohamed, 2011), and all of these roles directly relates to corporate governance (Gramling et al., 2004). As for the public sector, the role of internal auditors is increasing in order to combat the corruption risk. In this regard, internal auditors should have the ability, resources, and the power to obtain all information in the entire organization (Salehi, 2016). Accordingly, stakeholders will serve from possessing an effective IAF which will give the other cornerstones of corporate governance more value (Smet \& Mention, 2011). When internal auditors perform well, they will definitely promote and monitor the corporate governance system in an organization (Coetzee, 2010; Lenz \& Hahn, 2015).

However, several studies revealed that some factors, such as management support, competency, independence, internal audit department's size, and internal-external auditors' relationship, restrict the internal auditors' works (Badara \& Saidin, 2014; Nuijten, Twist, \& Steen, 2015; Salehi, 2016; Tackie, Marfo-Yiadom, \& Achina, 2016). Hence, IAF is still seen as an ineffective factor within the public sector institutions (Abuazza, Mihret, James, \& Best, 2015; Emmanuel, Ajanya, \& Audu, 2013). This ineffectiveness of IAF may not be associated to the capabilities or competencies of internal auditors themselves within the public sector, but it could be related to the extrinsic factors that should be taken into consideration. 
These extrinsic factors are not associated with the internal auditors' control within the organization, they might be related to some other factors including the support of top management.

Consequently, this study will examine the effect of the extrinsic factors (i.e., top management support, independence, complexity, and the size of the internal audit department) on the internal auditor's effectiveness. This study could be significant since there is a lack of studies regarding the internal auditors' effectiveness (Swinkels, 2012). This claim has been supported by Arena and Azzone (2009), Cohen and Sayag (2010), Endaya and Hanefah (2016), and Madawaki, Ahmi, \& Ahmad (2017) who stressed that there is a need for further studies to empirically examine the factors that influence internal auditors' effectiveness. In addition, according to the best knowledge of the researcher limited empirical research has incorporated the extrinsic factors mentioned above in order to identify their effect on the internal auditors' effectiveness, more specifically in the context of the public sector.

As for the task complexity factor, this is the first study that introduces this variable in the internal audit area. This kind of insertion will contribute to the body of knowledge by providing some insights into the IAF in both the Jordanian public sector as well other Arab countries due to the similarity in culture and developmental issues. Furthermore, the findings of this study could offer recommendations and solutions in order to overcome the IAF's deficiencies. Also, policy makers will be provided with new insights related to the factors affecting the internal auditors' effectiveness. These insights may help decision-makers (e.g., cabinet, senate, and parliament) to increase the effective use of IAF in the Jordanian public sector.

This paper is structured as follows: The next section reviews the literature review and develops the hypotheses. Additionally, it will address the methodology used and illustrate the main variables measured. Then, it will present the main findings of the analysis. Lastly, it will end with the discussion and conclusion.

\subsection{Literature Review and Hypotheses Development}

\subsubsection{Internal Audit Settings in Jordan}

Jordan, like other countries around the world, needs effective management and control of public funds and resources. Whereby, the effective internal audit department can lead to the best use of available resources (Ahmad, 2013), and enhance accountability in managing these resources (Babatunde, 2013). Hence, according to Section (31) of the Jordanian Prime Ministry (JPM) edict (1992), all institutions of public sector in Jordan are required to establish an internal audit unit (Rahahleh, 2006). Subsequently, to keep an IAF pace with developments and changes in the environment of these public sector; the edict has faced several amends, such as No. (3) 2011 and finally edict No. (11) For 2015 (JPM, 2015). The edict No. (3) 2011 was most important (JPM, 2011). Through the JPM edict 2011 No (3), the internal audit Standards of the public sector have been established in Jordan. The article (8) of the edict has determined the planned objectives of IAF that should be undertaken in the Jordanian public sector as it is: (i) the internal audit should ensure that all financial regulations, financial policies, and internal control instructions were met; (ii) it ensures that all financial operations were correctly registered and classified in the financial statements; (iii) it ensures that all available financial and human resources are allocated according to the plans and approved regulations; (iv) it verifies the effectiveness of the managerial and technical performance and ascertains the compliance of the work procedures with the predetermined plans and objectives; (v) it expresses an opinion on any financial, managerial or technical subject upon a senior management request (Al-Shqairat, 2006; JPM, 1992).

Furthermore, the JPM has declared a regulation that governs the IAF in the Jordanian public sector. In order to accomplish the various planned objectives of internal audit within each Jordanian public institution, the guidelines that govern the function have been determined (JPM, 1992). The edict stated that internal audit should be connected directly to the Minister in the ministries, and to the General Manager in the independent institutions. It also stressed the continuous support of the internal audit units by top management and the positive cooperation by all levels of the management. In addition, the proclamation ensures the implementation of the recommendations proposed by the internal audit unit (Al-Shqairat, 2006; JPM, 1992).

\subsubsection{Internal Auditors' Effectiveness}

Various studies have been conducted to examine the internal auditors' effectiveness (Alzeban \& Gwilliam, 2014; Badara \& Saidin, 2013; Erasmus \& Coetzee, 2018; Salehi, 2016). However, there is no a consensus regarding the measures used to evaluate internal auditors' performance. In fact, several modes of analysis and evaluation have been emerged. For example, the degree of compliance with the Institution of Internal Audit (IIA) standards has been suggested as an appropriate criterion to measure the effective performance (Fadzil, Haron, \& Jantan, 2005). On the other hand, other studies (Arena \& Azzone, 2009) have used the implementation of internal auditors' recommendations to measure effectiveness. According to Dittenhofer (2001), the output of audit activities is wider than satisfying auditees' (financial managers) need and this includes the ability of internal auditors to assess the achievement of auditees' objectives and 
provide reforms needed if the objectives are not met. This conceptualization clearly requires an evaluation of all those dimensions of business activity that are influenced by IAF activities, and this extends to include the organization performance. Thus, this study is in line with Alzeban and Gwilliam's (2014) study on factors influencing the internal auditors' effectiveness of the Saudi public sector. Hence, the present study uses auditees' perception as a quasi-external assessment of internal auditors' effectiveness; most of them have a background about the IAF and they are most relevant to avoid bias in such measurement. Nevertheless, very few studies have been carried out in the public sector and/or addressed the views of diverse stakeholders (Erasmus \& Coetzee, 2018). Consequently, this study seeks to examine the internal auditors' effectiveness from the financial managers' perception in the Jordanian public sector.

\subsubsection{Factors Affecting the Internal Auditors' Effectiveness}

The factors that influence the effectiveness of internal auditors have been seen as a controversial issue. In this regard, numerous factors have been addressed by several studies to investigate the ineffectiveness of IAF (Alzeban \& Gwilliam, 2014; Salehi, 2016; Tackie et al., 2016). For example, Ahmad, Othman, Othman, \& Jusoff (2009) found that lack of internal auditors' competence, understaffed departments and limited resources, lack of independence, negative view towards the role of internal audit by the auditees, and lack of the support from top management adversely impact on the effectiveness of internal audit. Similarly, Salehi (2016), and Alzeban, and Gwilliam (2014) have agreed that lack of top management support, competency, independence, internal audit department size, and internal-external auditors' cooperation are significant factors that lead to the deficiency of IAE, which, in turn, cause many problems in organizations. The extrinsic factors that restrict internal auditors' works were neglected, especially in the public sector where the objectives are usually complex and not easy to be measured (Schillemans \& Twist, 2016); the internal auditors are usually blamed and criticized when they fail to discover misuse of public resources or corruption cases. Hence, this study seeks to highlight the factors that are out of the internal auditors' control in public sectors.

\subsection{Research Model and Hypotheses}

The framework of the current study has been developed based on: i) a consideration of the literature on internal auditors' effectiveness; ii) the international standards for the Professional Practice of Internal Auditing "ISPPIA" of internal audit issued by IIA; and iii) the Jordanian legislation of public sector internal audit. The study has four independent variables (i.e., top management support, task complexity, independence, and internal audit department's size), and a dependent variable, which is, internal auditors' effectiveness. Hence, this paper indicates that the level of top management support to internal auditors, the degree of internal auditors' tasks complexity, the internal auditors' independence level, and the size of internal audit department effect on the effectiveness of internal auditors' (as shown in Figure 1).

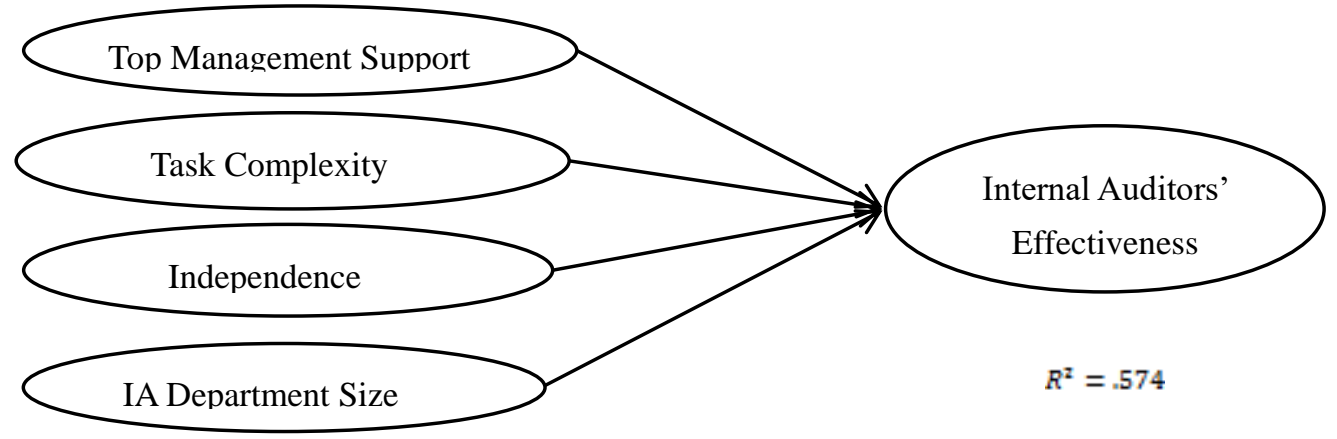

Figure 1. Research Model

Two underpinning theories have been addressed in the current study, namely, agency theory and resource-based theory. The agency theory explains the general notion of IAF within a firm. The theory states that the principal and the agent within a firm act rationally and use a contract to maximize their wealth (Jensen \& Meckling, 1976). The firm, therefore, provides contracts to reduce and control the moral hazard when the interests of principal and agent diverge (Blazovich, 2013). Hence, in order to achieve this goal, the agents and principals engage in such contracts to establish controlling processes regarding IAF (Adams, 1994). Accordingly, in the current study, the public sector represents the relationship between principal and agent. The public, acting as the principal (represented by the Parliament), and agent (Ministers/General Manager), must frequently account to the principal for their use and management of resources and the scope to which the public's objectives have been fulfilled. An effective IAF activity diminishes the inherent risks in the relationship between principal and agent. The principal depends on the auditor, who represents the third party, to give an independent and objective estimation of the precision of the agent's accounting and to report on whether the agent handles the resources in accordance with the principal's wishes. In doing so, internal auditors need sufficient sources and support 
to be able to carry out their tasks effectively, especially in the context of public sector as it is a complex environment (Pilcher et al., 2013).

Besides, (ISPPIA), "Resource Management Standard" (Institution of Internal Auditing [IIA], 2017, p. 11) declares that the chief audit executive must assure that the resources of internal audit are adequate to obtain the approved plan. This highlights the importance of the resource-based theory which encourages the researchers to use this theory as an underpinning theory for the current study. It also highlights the value of internal organizational resources as a fundamental source of organization performance (Barney, 199; Grant, 1991). Hence, an organization needs to look for unique properties that may provide high performance. This means that if an organization owns a number of distinct capabilities or internal resources to a higher extent, the organizations will be capable of implementing strategies that promote its efficiency and effectiveness (Barney, 1991). Thus, the present study illustrates the importance of the related internal organizational factors in promoting the success of IAF. The applicability of the resource-based view in examining IAF's effectiveness is based on the argument that if the organization owns a number of distinct internal resources to a greater extent, the effectiveness of internal auditors will be increased (Ahmad, 2013). In fact, the internal audit department should be treated as other departments of an organization as it needs some resources to provide its services (Kruger, Steyn, \& Kearney, 2002). Taking into consideration the results of previous studies along with authoritative professional organizations, particularly the IIA, and the complex environment of the public sector; this study has revealed four main extrinsic factors related to the effectiveness of internal auditors, namely, top management support, task complexity, independence, and size of internal audit department.

\subsubsection{Top Management Support for Internal Auditors}

Top management support is one of the important factors that affect internal auditors' effectiveness. The internal auditors, via top management support, can obtain adequate resources to accomplish their responsibilities (Lenz \& Hahn, 2015). In addition, the internal audit departments can obtain qualified staff, continuous training, adequate resources, and development (Alzeban \& Gwilliam, 2014; Cohen \& Sayag, 2010). Lack of top management support is a key factor that can restrict the internal auditor works. In this regard, Alzeban and Gwilliam (2014) argue that without such support, internal auditors are not properly independent and they will have inadequate resources. Hence, the top management support enables internal auditors to accomplish their established objectives within an organization and adds more value to the organization by enhancing organizational processes and performance.

Top management support strongly influences the effectiveness of internal audit in public sectors (Alzeban \& Gwilliam, 2012; Mihret \& Yismaw, 2007; Motubatse, Barac, \& Odendaa, 2015; Onumah \& Krah, 2012). In line with the resource-based theory, top management support is an internal organizational factor that can facilitate the success of IAF (Ahmad, 2013). It is argued that the support of top management is essential to enable internal auditors to achieve their objectives, which in turn, leads to the effectiveness of IAF. If the internal auditors obtain efficient support from the top management, this will lead to the high level of effectiveness in organizations. This argument leads to the first hypothesis:

H1: There is a positive relationship between top management support and internal auditors' effectiveness.

\subsubsection{Internal Auditors' Task Complexity}

According to the IIA's ISPPIA (Standards) revised 2012, internal audit activity has been implemented in various cultural and legal environments in organizations that differ in size, structure, complexity, and purpose as well as by individuals within or outside the organization. Thus, an organization should take into consideration the needs of internal auditors in light of variety of size, complexity, and structure of those organizations to be able to conduct their audit tasks effectively. With regard to public sector accounting growth, this sector definitely includes more complexity and extra risks associated to the corruption cases and high-risk of investments in different public entities (El-Tahan, 2016). Thus, the IAF has been developed to improve the organization's operations by providing a wide services range, including assurance and operational audits, and consulting management on a diversity of issues (IIA, 2017). Hence, these services have led to extending roles, and tasks of internal auditors within organizations, which, in turn, can reflect the complexity of their task.

In a complex environment, an auditor is required to exercise a high level of professional judgment (Abdolmohammadi \& Wright, 1987). Due to the relevant influence of task complexity on audit activity, auditors should use enhanced decision aids and training techniques (Bonner, 1994). When the task complexity level is obviously understood, audit tasks may be more effectively allocated to auditors to meet the diverse requirements of audit activities and then to enhance performance (Bonner, 1994). On the other hand, auditors make a poor performance for more complex audit activities because they may involve interconnected information that might be difficult to be analyzed or it requires more data for analysis (Iskandar \& Sanusi, 2011). This proposition has been proven by some studies which revealed that a high complexity level of the audit task is usually linked with a low-performance level of the external audit (Chang, Ho, \& Liao, 1997; Tan, Ng, \& Mak, 2002). However, few studies have addressed the effect of the task complexity on internal auditors' effectiveness in the public sector. Hence, this study seeks to address this issue using the agency theory. 
The researchers have used the agency theory for the first time in such study to illustrate the general notion of IAF within the Jordanian public institutions. In fact, public sectors depend on the IAF to produce an objective and independent evaluation of the accuracy of the agent's accounting and to inform on whether the agent handles the resources according to the principal's wishes. Therefore, the real need for the third party is to give assurance on the credibility of the financial reporting, compliance, performance results, and other measures based on several factors that involve the principal-agent relationship, such as the complexity (the principal may not own the ability or experience needed to manage the activity). Hence, the complexity of public sector affects internal auditors' task (Pilcher et al., 2013). Accordingly, the current study argued that task complexity affects the internal auditors' effectiveness negatively in the way that high complexity of the internal auditors' task may decrease the effectiveness of their performances. This argument leads to the second hypothesis:

$\mathrm{H} 2$ : There is a negative relationship between task complexity and internal auditors' effectiveness.

\subsubsection{Internal Auditors' Independence}

The independence is one of the cornerstones and a critical condition to the internal auditors' effectiveness (Christopher, Sarens, \& Leung, 2009). This is confirmed by the IIA in the ISPPIA that "the internal audit activity must be independent, and internal auditors must be objective in performing their work." (IIA, 2017, p.3) The independence is defined as the freedom from conditions that threaten objectivity or the appearance of objectivity. If the auditors are independent, their opinion will enhance the financial reports' credibility (Arens, Elder, Beasley, \& Hogan, 2016). Bou-Raad (2000) concludes that the capacity of the IAF is evaluated based on the extent of internal auditors' independence from management and other operating works. Hence, internal auditors' independence raises the effectiveness of IAF because independence may diminish the level of discrepancy between loyalty to specific managers and loyalty to the employer and give the internal auditors an optimistic work environment in which they can perform their task without pressure or restricts (Abu-Azza, 2012).

The independence factor is related to resource-based theory. This theory includes all assets, capabilities and organization attributes which are controlled by an organization and enables it to perform strategies that raise its effectiveness (Barney, 1991). When internal auditors have inadequate resources, this means that they are not properly independent (Alzeban \& Gwilliam, 2014). These resources are considered as any assets that could be used to assist an organization accomplishing its objectives and performing well (Bryson et al., 2007). In this vein, the internal auditors' independence can be a key role of the internal auditors' effectiveness (Arens et al., 2014). This leads to the following hypothesis:

H3: There is a positive relationship between independence and internal auditors' effectiveness.

\subsubsection{Internal Audit Department Size}

According to the resource-based theory, the size of internal audit department is one of the main internal resources in an organization that assists internal auditors in conducting their responsibilities competently, and thus, it leads to the effectiveness of IAF. Under-sized internal audit department cannot fulfill the objectives set forth in the legislation when IAF activity is influenced by the inadequacy of allocated resources (Dascalu, 2016). IAF is a complex process that requires multidisciplinary sets of knowledge and skills to perform properly in the organizations (Susmanschi \& Georgescu, 2014). The large size of internal audit departments is more expected to have a hierarchical administration structure within any organization where they will be provided with more empowerment to conduct their works effectively.

On the other hand, auditors in under-sized internal audit department are likely to perform a wider variety of responsibilities and participate in various kinds of engagements (Prawitt, 2003). Hence, when there is enough number of internal audit staff, the effectiveness of internal auditors' performance will obviously increase (Brierley et al., 2001; Rogala \& Wereda, 2015; Salehi, 2016). This is particularly true in the public sector which has been described as a sector with additional risks, extra complexity, and cases of corruption in several public entities (El-Tahan, 2016; Pilcher, 2014). Consequently, this study argues that sufficient size of the internal audit department will lead to the high effectiveness of internal auditors. This leads to the fourth hypothesis:

H4: There is a positive relationship between internal audit department size and internal auditors' effectiveness.

\section{Methodology}

This paper focuses on the extrinsic factors influencing internal auditors' effectiveness in Jordanian public sector as the population of this study. As documented by Jordanian Audit Bureau (JAB) (2006) the public sector which is under the JAB's control (as an external auditor) includes four groups of institutions namely: 25 ministries, 235 governorates, 17 independent bodies, and 10 public universities (JAB, 2015). Hence, the total population of this study is 287 Jordanian public institutions. The whole population in the study will be included as a sample of the study. In the context of internal audit in public sector, two groups of respondents (Alzeban, \& Gwilliam, 2014; Cohen, \& Sayag, 2010; Salehi, 2016) will be used in this study, namely auditees (financial manager) and internal auditors' managers. 
The data was gathered from two sets of surveys: (1) financial managers to cover the dependent variable and (2) internal auditor managers to cover independent variables. The perceptions of the financial managers were used to obtain a quasi-external evaluation of the effectiveness of internal auditors of the same entities where internal auditor managers were surveyed to provide indicators of the factors affecting the effectiveness of the internal auditors. The questionnaires were closed-ended, with five-point Likert scale, aiming at enabling the respondents to report their views with concerned statements using different degrees from strongly agree to strongly disagree.

The survey questionnaires were distributed to 287 financial managers and internal auditor managers in the Jordanian public sectors exposed to audit by the Jordanian audit bureau. Out of them, 117 usable responses were received from both the categories of respondents. The questionnaire for the financial managers (Auditees) included 15 items. The total of these 15 items was combined to give a single measurement of the overall effectiveness of internal auditors for measuring the dependent variable. The purpose of this questionnaire was to obtain a quasi-external evaluation of the internal auditors' effectiveness. Likewise, the second questionnaire, which included 24 items, was utilized to measure all the independent variables. Hence, a survey for internal auditors' managers covered the factors influencing internal auditors' effectiveness. These procedures were followed in order to minimize any form of bias.

\subsection{Measurement}

Internal auditors' effectiveness was measured using 15 items adapted from Alzeban and Gwilliam (2014) and Salehi (2016). The internal auditors' effectiveness was conceptualized as the capability to plan, assessment of internal control systems, evaluation of the compatibility of results with placed objectives and goals, enhancement of the entity's productivity, assessment, and enhancement of risk management, internal auditors current and future recommendations. On the other hand, the independent variables which include support of top management, complexity, independence, and the size of IA department, were measured by using 24 items divided as follows: Firstly, support of top management for internal auditors was measured using six items adapted from Salehi (2016). These items were aimed to, i) help internal auditors to conduct their duties and responsibilities; ii) provide reports that are given to the management by internal auditors; iii) management's response to reports produced by internal auditors; $x$ ) involvement in planning internal audit; internal audit department is large enough to successfully carry out its duties and responsibilities. xi) and provide internal auditors with sufficient resources.

Secondly, task complexity of the internal auditors was measured by eight indicators adapted from Zimmer, Henry, and Butler (2007). These indicators are unstructured audit operations, dealing with ad hoc, non-routine audit works, involving more than one place or branch, tasks that have never existed in that way before, variety of the problems or operations for which internal audit needs data, thinking about audit issues and the associated data in a new way, and spending time in thinking about how best to address audit works before internal audit begins auditing. Thirdly, the internal auditor's independence (IAI) was measured using nine items adapted from Salehi (2016). The items in this variable were independence 's level, direct linkage with the board of directors and top management, level of reporting, interference, conflict of interests, unrestricted access to all employees and departments, appointing and dismissing the head of internal audit department, performance, and non-audit activities. Lastly, the internal audit department size (IADS) was measured by the number of internal audit staff worked within it. This principle has been adopted from Alzeban and Gwilliam (2014).

\section{Results}

The Statistical Package for Social Sciences (SPSS) 19.0 and Partial Least Square-Structural Equation Modeling (PLS-SEM) were used for data analysis. Data cleaning and descriptive statistics were run by utilizing the SPSS 19.0. Table 1 provides descriptive statistics for the study constructs using SPSS. Mean scores of the variables were over the mid-point on the one to five-scales, while the mean score for the internal audit department size was less than the mid-point which suggests that the internal audit department within Jordanian public sector is under-sized compared to its requirement. For the effectiveness, results infer that the internal auditors in the Jordanian public sector are still inclined towards a traditional approach in terms of reaching the specified objectives focusing on compliance with procedures, plans, regulations, and policies of the public institutions (mean score 3.067). 
Table 1. Mean and standard deviation of variables

\begin{tabular}{lcc}
\hline Constructs & Mean & Std. Deviation \\
\hline Internal auditors' effectiveness & 3.067 & .811 \\
Top management support & 3.134 & .887 \\
Internal auditors' independence & 3.153 & .756 \\
Task complexity & 3.642 & .934 \\
Internal audit department size & 1.601 & .881 \\
\hline
\end{tabular}

The PLS-SEM was utilized to confirm the research hypotheses. PLS is popular for path modeling approach among scientists and practitioners (Alsaad, Mohamad, \& Ismail, 2015, 2017). PLS allows assessment of relationships between latent variables with several indicators even when there is a small sample size. In addition, it can be used easily to model hierarchical constructs at several levels of abstraction (Hair, Ringle, Sarstedt, \& Mark, 2011). PLS also operates proficiently when the introduced model includes many structural path relationships (Alsaad, Yousif, \& AlJedaiah, 2018).

PLS path model comprises two primary models: (1) measurement model; and (2) structural model. The measurement model examines the relationship between the constructs and their respective measures (Hair et al., 2011). The structural model, on the other hand, portrays relationship between the constructs. The first stage in PLS analysis is to perform reliability and validity checks for the measurement model. In this regard, Hair et al. (2016) state that items with outer loadings between .40 to .70 must be removed from the scale only if removing these items leads to a rise in the Composite Reliability (CR) or the Average Variance Extracted (AVE) is over the proposed threshold value. As a result, there was no indicator loading less than .40. Correspondingly, some items that ranged between .40 and .70 were kept. Hair et al. (2014) suggest to increase the values of AVE and CR of the related latent variables to the minimum acceptable value, thus necessitating the removal of a number of items from these constructs to establish reasonable reliability, namely, IAE13, IAE14, IAE15, IAI2, IAI3, IAI4, and IAI8. Hence, after removing items that were poorly loading, 31 from 38 items were retained for the model. Deleting some items is considered normal and common in most studies that use questionnaires (Alshirah, 2018; Ayuba, Saad, \& Ariffin, 2016; Hair, Hult, Ringle, \& Sarstedt, 2016).

For convergent validity, the results of CR and cross loading of the items after deletion are presented in Table 2 . The AVEs of all variables were over the threshold value of .50. The square roots of the AVEs for all the variables were counted to evaluate the discriminant validity as shown in Table 3. The results confirm that the square roots of the AVE scores were all higher than the correlations among the constructs, demonstrating discriminant validity. The results also demonstrate that the composite reliabilities of all variables were in the extent of the threshold of .70 which affirmed the reliability of the model. Afterwards, the collinearity of the construct was examined. The variance inflation factor (VIF) has been used to detect multicollinearity (Petter, Straub, \& Rai, 2007). VIF values of all constructs were under the threshold of five. This confirms that there is no issue of collinearity found. Based on the above discussion, the analyses reviewed present an evidence of the validity of the measurement model of the current study.

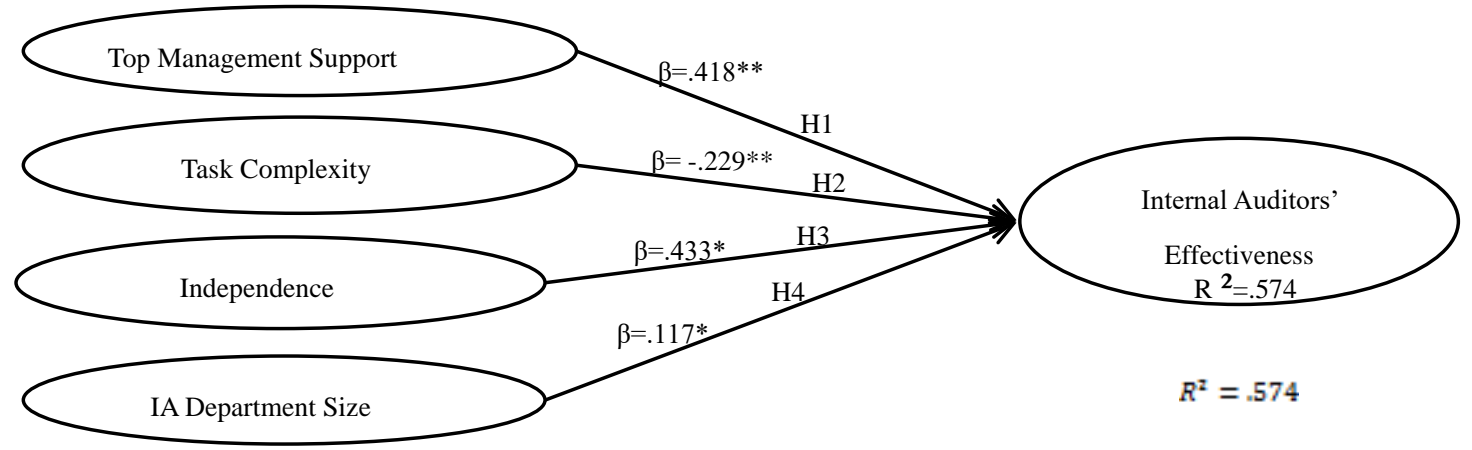

Significant at $p<0.05^{*}, p<0.01 * *$

Figure 2. Structural Model 
Table 2. Indicators Reliability, Cross Loading, CR, VIF, and Convergent Validity (after deletion)

\begin{tabular}{|c|c|c|c|c|c|c|c|}
\hline & \multirow[t]{2}{*}{ VIF } & \multicolumn{6}{|c|}{ Cronbach's alpha } \\
\hline Construct name & & & IADS & IAE & IAI & $\mathrm{TC}$ & TMS \\
\hline $\begin{array}{l}\text { Internal audit } \\
\text { department size }\end{array}$ & $\begin{array}{l}\text { Singe-item } \\
\text { construct }\end{array}$ & IADS & $\begin{array}{c}\text { Singe-item } \\
\text { construct }\end{array}$ & .069 & -.074 & .146 & .048 \\
\hline Internal & 1.982 & IAE1 & .28 & .718 & .388 & -.166 & .335 \\
\hline auditors' & 1.868 & IAE10 & .14 & .658 & .313 & -.165 & .442 \\
\hline effectiveness & 2.011 & IAE11 & .064 & .704 & 497 & -.277 & .462 \\
\hline & 1.703 & IAE12 & .038 & .633 & .357 & -.167 & .342 \\
\hline AVE: .55 & 2.041 & IAE2 & .046 & .702 & .426 & -.269 & .299 \\
\hline CR: .93 & 1.97 & IAE3 & .048 & .712 & .468 & -.081 & .364 \\
\hline & 2.964 & IAE4 & .078 & .761 & .428 & -.231 & .42 \\
\hline & 2.858 & IAE5 & -.043 & .762 & .483 & -.248 & .426 \\
\hline & 2.363 & IAE6 & -.014 & .754 & .427 & -.21 & .478 \\
\hline & 2.084 & IAE7 & -.072 & .726 & .402 & -.276 & .433 \\
\hline & 2.109 & IAE8 & .026 & .759 & .443 & -.213 & .46 \\
\hline & 1.971 & IAE9 & .037 & .676 & .372 & -.148 & .436 \\
\hline Internal & 1.302 & IAI1 & -.075 & .355 & .641 & .034 & .295 \\
\hline auditors' & 1.269 & IAI5 & -.061 & .378 & .652 & -.108 & .247 \\
\hline independence & 1.299 & IAI6 & .029 & .53 & .732 & -.199 & .26 \\
\hline & 1.822 & IAI7 & -.13 & .373 & .754 & -.068 & .159 \\
\hline AVE: .50 & & & & & & & \\
\hline CR: .83 & 1.682 & IAI9 & -.058 & .381 & .729 & -.091 & .156 \\
\hline Task & 2.176 & $\mathrm{TC} 1$ & .035 & -.221 & -.14 & .796 & -.041 \\
\hline Complexity & 2.957 & TC2 & .172 & -.229 & -.111 & .844 & -.01 \\
\hline & 2.359 & TC3 & .118 & -.281 & -.108 & .831 & -.075 \\
\hline AVE: .65 & 2.293 & TC4 & .1 & -.125 & -.057 & .773 & .035 \\
\hline CR: .94 & 2.205 & TC5 & .146 & -.338 & -.182 & .832 & -.151 \\
\hline & 2.432 & TC6 & .099 & -.168 & -.042 & .799 & -.002 \\
\hline & 2.285 & TC7 & .158 & -.17 & -.005 & .794 & .017 \\
\hline & 2.099 & TC8 & .097 & -.191 & -.146 & .758 & -.023 \\
\hline Top & 1.416 & TMS1 & .003 & .398 & .191 & -.022 & .673 \\
\hline management & 1.563 & TMS2 & .115 & .397 & .218 & -.058 & .718 \\
\hline support & 1.49 & TMS3 & -.013 & .486 & .265 & -.01 & .731 \\
\hline & 1.712 & TMS4 & .073 & .43 & .254 & 0 & .764 \\
\hline AVE: .526 & 1.664 & TMS5 & -.021 & .374 & .192 & -.004 & .742 \\
\hline CR: .87 & 1.538 & TMS6 & .057 & .396 & .263 & -.167 & .72 \\
\hline
\end{tabular}

Table 3. Discriminant Validity

\begin{tabular}{lccccc}
\hline & IADS & IAE & IAI & TC & TMS \\
\hline Internal audit department size & $\begin{array}{c}\text { Singe-item } \\
\text { construct }\end{array}$ & & & & \\
Internal auditors' effectiveness & .069 & .715 & & & \\
Internal auditors' independence & -.074 & .587 & .703 & & \\
Task Complexity & .146 & -.29 & -.137 & .804 & \\
Top management support & .048 & .575 & .32 & -.058 & .725 \\
\hline
\end{tabular}

For the structural paths, the results of both standardized path coefficients and their significance values were utilized for examining the hypotheses. Thereby, our study used the PLS algorithm and the standard bootstrapping procedure with 1000 bootstrap samples and 117 cases to evaluate the significance of the path coefficients $(\beta)$ using a one-tailed test (Hair et al., 2014a). As shown in Table 4, the result provides sufficient support to H1, H2, H3, and H4. Overall, the results prove that path coefficients of constructs are both strong and significant. The path coefficient $(\beta)$ from top management support 
to internal auditors' effectiveness is positive and significant $(\beta=0.418 ; p<.01)$, hence, supporting H1. The results suggest that as the support of top management increases, the effectiveness of internal auditors increases. With regard to $\mathrm{H} 2$, the result revealed existence of a significant degree of negative relationship between task complexity and internal auditors' effectiveness $(\beta=-.223, p<.01)$, indicating that as the extent of task complexity increases, the effectiveness of internal auditors decreases. The internal auditors' independence was found as positive and significant $(\beta=.431 ; p>.01)$, showing that when the extent of internal auditors' independence increases, the effectiveness of internal auditors increases in the same proportion. Internal audit department size was significant and positive $(\beta=114 ; p<.05)$, indicating that as the large extent of internal audit department size is found; internal auditors' effectiveness increases accordingly. Finally, the result of the PLS algorithm presents that the model represents .574 of the variance.

Table 4. Result of Hypotheses Testing

\begin{tabular}{lccccc}
\hline Hypothesis testing & $\begin{array}{c}\text { Path } \\
\text { coefficient }\end{array}$ & T statistics & $\boldsymbol{p}$-values & Effect size & Result \\
\hline H1: TMS -> IAE & .418 & 6.86 & $0.00^{*}$ & .262 & Supported \\
H2: TC -> IAE & -.223 & 3.01 & $.001^{*}$ & .083 & Supported \\
H3: IAI -> IAE & .431 & 8.45 & $0.00^{*}$ & .172 & Supported \\
H4: IADS -> IAE & .114 & 1.79 & $.037^{* *}$ & .026 & Supported \\
\hline
\end{tabular}

Note: $* p$-values <.01; **p-values < .05. TMS - top management support; TC - task complexity; IAI - internal auditors' independence; IADS - internal audit department size.

As shown in Table 4, the findings of the PLS path model illustrated that all variables have a significant effect on the internal auditors' effectiveness. More precisely, the findings referred that the top management support (H1), is positively and significantly effect on internal auditors' effectiveness. This is confirming that the top management support is one of the main drivers to the effectiveness of internal auditors in the Jordanian public sector. Conversely, the task complexity (H2) has found to affecting the internal auditors' effectiveness negatively and significantly. This finding is not surprising, due to the complex environment of the Jordanian public sector, which is effect negatively on the internal auditors' tasks. Besides, the findings revealed that the internal auditors' independence (H3) has a positive and significant effect on the effectiveness of internal auditors. This is due to the significant issue of internal auditors' independence in the Jordanian public sector. Finally, the internal audit department size (H4) found to have a positive and significant effect on internal auditors' effectiveness. This confirmed that the size of the internal audit department is one of the main resources that assist internal auditors in conducting their responsibilities competently. In this vein, the size of the internal audit department should be proper with the diversities forms, sizes and objectives of the Jordanian public institutions.

\section{Discussion}

Earlier studies have posited that the effectiveness of internal auditors is affected by several factors (D'Onza \& Sarens, 2018; Erasmus \& Coetzee, 2018; Nuijten et al., 2015; Salehi, 2016). The current study has supported this notion by introducing extrinsic factors (i.e., top management support, independence, complexity, and internal audit department size) affecting the effectiveness of internal auditors. In line with the resource-based theory, the results found that top management support, independence of internal auditors, and internal audit department size affect the effectiveness of internal auditors. Corresponding to the agency theory, the complexity of internal auditors' tasks affects the effectiveness of their works, as a third party between the public and the government. Thus, using these theories enriches the body of knowledge in the research field of the internal audit.

The findings of this study are also aligned with the results of prior studies. More specifically, this study found that the support of top management positively affects the effectiveness of internal auditors. This finding agrees with previous studies (Alzeban \& Gwilliam, 2014; Cohen \& Sayag, 2010; Lenz \& Hahn, 2015). For example, Alzeban and Gwilliam (2014) found that the support of top management contributes to perceive IAF effectiveness. With the support of the top management, internal auditors can get adequate resources to perform their responsibilities and duties as well as the internal audit department can get qualified staff and present continuous training and improvement (Cohen \& Sayag, 2010).

Prior studies revealed that a high complexity level of audit task is often associated with weak external audit performance (Tan, Ng, \& Mak, 2002; Chang, Ho, \& Liao, 1997). The present study found a similar finding where task complexity has a negative effect on the effectiveness of internal auditors. Auditors make a poor performance for extra complexity of audit tasks, this issue could happen due to the interconnected information that might be hard to be analyzed (Iskandar \& Sanusi, 2011). The results of this study detected that the independence of internal auditors has a positive effect on the IAE. This 
finding agrees with Arens et al. (2014) who explain that when the auditors are independent, their opinion will enhance credibility of the financial reports (Arens et al., 2016). In addition, the findings of this study confirm that the internal audit department's size has a positive effect on the internal auditors' effectiveness. Hence, when there is enough number of internal audit staff, the effectiveness of internal auditors will increase. Similar findings were reported by Rogala and Wereda (2015) and Salehi (2016).

\section{Conclusion}

The study was conducted with the objective of examining the effect of extrinsic factors on internal auditors' effectiveness. To that end, two sets of surveys were employed: survey results from the financial managers to examine the dependent variable; and survey results from the internal auditors' managers to cover the independent variables. The agency theory and resource-based view were employed as the underpinning theories for this study. The results of this substantially proved that top management support, internal auditors' independence, and internal audit department size affect the effectiveness of the internal auditors positively, while task complexity affects their effectiveness adversely.

The finding of the current study reveals the way in which extrinsic factors affect the internal auditors' effectiveness in the Jordanian public sector. Thus, this study adds to the current literature on internal auditing in Jordan regarding this sector as the previous studies focused on the private sector (Salameh, Al-Weshah, Al-Nsour, \& Al-Hiyari, 2011; Alsukker, 2014). Concerning the significance of the public sector within the Jordanian economy, this study improves the understanding of the extrinsic factors as they affect the internal auditors' ability to achieve the assigned goals in Jordan and of those factors that are out of internal auditors' control and underlying internal auditors' effectiveness.

Some unique theoretical and practical implications are revealed from this study. In the previous studies on the effectiveness of internal audit, scholars have given attention to the factors influencing the effectiveness of IAF in general from different perceptions. Instead of grouping such factors into several themes from internal auditors to facilitate the understanding and the way of dealing with them in order to be clearer for the decision-makers, this study has grouped respective factors under extrinsic factors' theme which are relevant to the Jordanian public sector environment that restrict the effectiveness of internal auditors. Besides, studying the extrinsic factors of internal auditors' effectiveness in the Jordanian public sector context is an interesting study that can produce insights into various countries alike, especially for Arab countries.

This study also contributed to the internal auditors' effectiveness in relation to two theories employed in this study, which are the agency theory and resource-based theory. First, prior literature has adopted the agency theory in the private sector, while this study has introduce agency theory for the first time in the public sector (employing the IAF in the public sector as an agent between parliament and government) to explain the general nation of IAF. Correspondingly, the resource-based theory has been adopted in the current study where IAF is an agent that requires sufficient resources and support so that internal auditors can carry out the tasks effectively. The findings of the current study supported the resource-based and agency theory predictions. Thus, the findings from this study helps to advance the knowledge relating to IAF landscape in Jordan for the academicians and public at large.

In terms of practicality, empirical findings suggest that the Jordanian government should pay great attention to their IAF and its effectiveness, and keep aware that they should allocate the internal resources of public institutions. By having an effective IAF, it helps to reduce corruption in the public sector. The findings may help Cabinet, Senate and Parliament to strengthen the public sector management by reinforcing accountability, improving the economy, and effectiveness of the government bodies and the associated organizations.

Finally, when interpreting the results, it is important to consider several issues, as there is no research without limitations. This study only addressed some extrinsic factors that determine the internal auditors' effectiveness in Jordanian public sector. Thus, future studies may consider to investigate other factors that might restrict IAF performance, such as organizational culture.

\section{References}

Abdolmohammadi, M., \& Wright, A. (1987). An examination of the effects of experience and task complexity on audit judgments. Accounting Review, 62(1), 1-13. http://www.jstor.org/stable/248042

Abu-Azza, W. (2012). Perceived effectiveness of the internal audit function in Libya: a qualitative study using institutional and Marxist theories (Unpublished Doctoral Thesis, University of Southern Queensland).

Ahmad, H. N., Othman, R., Othman, R., \& Jusoff, K. (2009). The effectiveness of internal audit in Malaysian public sector, Journal of Modern Accounting and Auditing, 5(9), 53- 62.

Ahmad, H. N. (2013). Internal Audit Effectiveness in Malaysian Local Authorities: Internal auditors' Perspectives (Unpublished Doctoral Thesis, University Utara Malaysia). 
Alsaad, A. K., Yousif, K. J., \& AlJedaiah, M. N. (2018). Collaboration: the key to gain value from IT in supply chain. EuroMed Journal of Business, 13(2), 214-235.

Alsaad, A., Mohamad, R., \& Ismail, N. A. (2015). Perceived desirability and firm's intention to adopt business to business e-commerce: A test of second-order construct. Advanced Science Letters, 21(6), 2028-2032.

Alsaad, A., Mohamad, R., \& Ismail, N. A. (2017). The moderating role of trust in business to business electronic commerce (B2B EC) adoption. Computers in Human Behavior, 68, 157-169.

Alsukker, A. S. M. (2014). The influence of objectivity, competence, and work performance on external auditors' judgements relating to the internal audit function in Jordan (Unpublished Doctoral Thesis, Australian Catholic University).

Alzeban, A. (2010). The effectiveness of internal audit in the Saudi public sector (Unpublished Doctoral Thesis, University of Exeter).

Alzeban, A., \& Gwilliam, D. (2012). Perceptions of managers and internal auditors as to factors affecting the effectiveness of internal audit in the public sector context. In 10th European Academic Conference on Internal Audit and Corporate Governance. University of Verona: Italy.

Alzeban, A., \& Gwilliam, D. (2014). Factors affecting the internal audit effectiveness: A survey of the Saudi public sector. Journal of International Accounting, Auditing and Taxation, 23(2), 74-86. https://doi.org/10.1016/j.intaccaudtax.2014.06.001.

Arens, A. A., Elder, R. J., Beasley, M. S., \& Hogan, C. E. (2016). Auditing and assurance services. Pearson.

Badara, M. S. (2014b). Antecedents of Internal Audit Effectiveness: a moderating effect of effective audit committee at local government in Nigeria (Unpublished Doctoral Thesis, University Utara Malaysia).

Badara, M. S., \& Saidin, S. Z. (2013a). Antecedents of internal audit effectiveness: A moderating effect of effective audit committee at local government level in Nigeria. International Journal of Finance and Accounting, 2(2), 82-88. https://doi: 10.5923/j.ijfa.20130202.05

Bonner, S. E. (1994). A model of the effects of audit task complexity. Accounting, Organizations and Society, 19(3), 213-234. https://doi.org/10.1016/0361-3682(94)90033-7

Bou-Raad, G. (2000). Internal auditors and a value-added approach: the new business regime. Managerial Auditing Journal, 15(4), 182-187. https://doi. org/10.1108/02686900010322461

Chang, C. J., Ho, J. L., \& Liao, W. M. (1997). The effects of justification, task complexity and experience/training on problem-solving performance. Behavioral Research in Accounting, Supplement Conference Papers, 9, 98-116.

Christopher, J., Sarens, G., \& Leung, P. (2009). A critical analysis of the independence of the internal audit function: evidence from Australia. Accounting, Auditing \& Accountability Journal, 22(2), 200-220.

Coetzee, G. P. P. (2010). A risk-based audit model for internal audit engagements (Doctoral dissertation, University of the Free State).

Cohen, A., \& Sayag, G. (2010). The effectiveness of internal auditing: an empirical examination of its determinants in Israeli organisations. Australian Accounting Review, 20(3), 296-307. https://doi:10.1111/j.1835-2561.2010.00092.x

Dascalu, E. D. (2016). Factors supporting an adequate sizing of internal audit departments in the public sector. The Audit Financiar journal, 14(138). http://revista.cafr.ro/temp/Article_9479.pdf

Dittenhofer, M. (2001). Internal auditing effectiveness: An expansion of present methods. Managerial Auditing Journal, 16(8), 443-450. https://doi.org/10. 1108/ EUM0000000006064

El-Tahan, S. Y. (2016). Adoption of internal auditing in developing countries: Egyptian public sector (Master Thesis, The American University in Cairo).

Emmanuel, O. E., Ajanya, M. A., \& Audu, F. (2013). An assessment of internal control audit on the efficency of public sector in Kogi State Nigeria. Mediterranean Journal of Social Sciences, 4(11), 717. https://doi:10.5901/mjss.2013.v4n11p717

Endaya, K. A., \& Hanefah, M. M. (2016). Internal auditor characteristics, internal audit effectiveness, and moderating effect of senior management. Journal of Economic and Administrative Sciences, 32(2), 160-176. https://doi.org/10.110 8/JEAS-07-2015-0023

Gramling, A. A., Maletta, M. J., Schneider, A., \& Church, B. K. (2004). The role of the internal audit function in corporate governance: A synthesis of the extant internal auditing literature and directions for future research. 
Journal of Accounting literature, 23(1), 194-244.

Hair, J. F., Ringle, C. M., \& Sarstedt, M. (2011). PLS-SEM: Indeed a silver bullet. Journal of Marketing theory and Practice, 19(2), 139-152.

Hair Jr, J. F., Hult, G. T. M., Ringle, C., \& Sarstedt, M. (2016). A primer on partial least squares structural equation modeling (PLS-SEM). Sage Publications.

Hair Jr, J., Sarstedt, M., Hopkins, L., \& Kuppelwieser, V. G. (2014). Partial least squares structural equation modeling (PLS-SEM) An emerging tool in business research. European Business Review, 26(2), 106-121. https://doi.org/10.1108/EBR-10-2013-0128

IIA (2012). Internal Auditing: Assurance, Insight, and Objectivity, the Institute of Internal Auditors, Altamonte Springs, FL.

IIA (2017). International Standards for the Professional Practice of Internal Auditing (STANDARDS). The Institute of Internal Auditors, Standards and Guidance. Retrieved https://na.theiia.org/standards-guidance/mandatory-guidance/Pages/Standards.aspx.

Iskandar, T. M., \& Sanusi, Z. M. (2011). Assessing the Effects of Self-Efficacy and Task Complexity on Internal Control Audit Judgment. Asian Academy of Management Journal of Accounting \& Finance, 7(1), 29-52.

Jordanian Primary Minister (1992). Prime Minister's edict no. (31) for the year 1992. Retrieved From http://www.awqaf.gov.jo/Pages/viewpage.aspx?pageID=174

Madawaki, A., Ahmi, A., \& Ahmad, H. N. (2017). Internal audit function: a comparison between private and public sector in Nigeria. In SHS Web of Conferences (Vol. 34, p. 01004). EDP Sciences.

Mihret, D. G., \& Yismaw A. W. (2007). Internal audit effectiveness: an Ethiopian public sector case study, Managerial Auditing Journal, 22(5), 470-484. https://doi.org/10.1108/02686900710750757.

Moeller, R. (2004). Managing internal auditing in a post-SOA world. Journal of Corporate Accounting \& Finance, $15(4), 41-45$.

Mohamed, Z. (2011). The effects of audit committee and internal audit attributes on internal audit quality and audit fees (Doctoral dissertation, Multimedia University (Malaysia)).

Motubatse, N., Barac, K., \& Odendaal, E. (2015a). Perceived challenges faced by the internal audit function in the South African public sector: A case study of The National Treasury. African Journal of Science, Technology, Innovation and Development, 7(6), 401-407. https://doi:10.1080/20421338.2015.1096510

Nuijten, A., Twist, M., \& Steen, M. (2015). Auditing interactive complexity: Challenges for the internal audit profession. International Journal of Auditing, 19(3), 195-205. https://doi: 10.1111/ijau.12049

Onumah, J. M., \& Krah, R. Y. (2012). Barriers and catalysts to effective internal audit in the Ghanaian public sector. Accounting in Africa. 12(1), 177-207. https://doi:10.1108/S1479-3563(2012) 000012A012

Pilcher, R. (2014). Role of internal audit in Australian local government governance: a step in the right direction. Financial Accountability \& Management, 30(2), 206-237. https://doi: 10.1111/faam.12034

Pilcher, R., Gilchrist, D., Singh, H., \& Singh, I. (2013). The interface between internal and external audit in the Australian public sector. Australian Accounting Review, 23(4), 330-340. https://doi: 10.1111/auar.12032

Prawitt, D. F. (2003). Managing the internal audit function. Research Opportunities in Internal Auditig, the Institute of Internal Auditors, 171-230.

Rogala, P., \& Wereda, W. (2015). Factors Affecting the Effectiveness of Internal Audits of Quality Management System. Hyperion International Journal of Econophysics \& New Economy, 8(2), 401-408.

Salameh, R., Al-Weshah, G., Al-Nsour, M., \& Al-Hiyari, A. (2011). Alternative internal audit structures and perceived effectiveness of internal audit in fraud prevention: evidence from Jordanian banking industry. Canadian Social Science, 7(3), 40-50.

Salehi, T. (2016). Investigation Factors Affecting the Effectiveness of Internal Auditors in the Company: Case Study Iran. Review of European Studies, 8(2), 224. http://dx.doi.org/10.5539/res.v8n2p224

Schillemans, T., \& Twist, M. (2016). Coping with Complexity: Internal Audit and Complex Governance. Public Performance \& Management Review, 40(2), 257-280. http://dx.doi.org/10.1080/15309576.2016.1197133

Smet, D., \& Mention, A. L. (2011). Improving auditor effectiveness in assessing KYC/AML practices: Case study in a Luxembourgish context. Managerial Auditing Journal, $182-203$. 
https://doi.org/10.1108/02686901111095038

Susmanschi, G., \& Georgescu, L. S. (2014). Performance evaluation of internal audit. Economics, Management, and Financial Markets, 9(1), 485-491.

Tackie, G., Marfo-Yiadom, E., \& Achina, S. O. (2016). Determinants of Internal Audit Effectiveness in Decentralized Local Government Administrative Systems. International Journal of Business and Management, 11(11), 1833-3850. http://dx.doi.org/10.5539/ijbm.v11n11p184

Tan, H. T., Ng, T. B. P., \& Mak, B. W. Y. (2002). The effects of task complexity on auditors' performance: The impact of accountability and knowledge. Auditing: A Journal of Practice \& Theory, 21(2), 81-95. https://doi.org/10.2308/aud.2002.21.2.81

Zimmer, J. C., Henry, R. M., \& Butler, B. S. (2007). Determinants of the use of relational and non-relational information sources. Journal of Management Information Systems, 24(3), 297-331.

\section{Copyrights}

Copyright for this article is retained by the author(s), with first publication rights granted to the journal.

This is an open-access article distributed under the terms and conditions of the Creative Commons Attribution license (http://creativecommons.org/licenses/by/4.0/). 